\title{
Palmistichus elaeisis (Hymenoptera: Eulophidae) as an indicator of toxicity of herbicides registered for corn in Brazil
}

\author{
Claubert W.G. de Menezes ${ }^{1}$, Marcus A. Soares ${ }^{1 *}$, Arley J. Fonseca ${ }^{1}$, José B. dos Santos ${ }^{1}$, \\ Silma da S. Camilo ${ }^{1}$, and José C. Zanuncio ${ }^{2}$
}

\begin{abstract}
The diversity of plants in agricultural systems benefits natural enemies. Herbicides are used in weed management in corn (Zea mays L.) to reduce competition and productivity losses, but they can impact natural enemies and contaminate the environment. The objective was to evaluate toxicity of herbicides on pupae parasitoid Palmistichus elaeisis Delvare and LaSalle, 1993 (Hymenoptera: Eulophidae). The treatments were represented by the host pupae Tenebrio molitor L., 1785 (Coleoptera: Tenebrionidae) and herbicides atrazine, nicosulfuron, paraquat, and tembotrione in commercial doses compared to a control treatment with water. Pupae of $T$. molitor were immersed in the solution of herbicides and exposed to parasitism by six females of $P$. elaeisis each. The herbicides atrazine and paraquat were highly toxic and, therefore, not selective to $P$. elaeisis. Nicosulfuron reduced the sex ratio of $P$. elaeisis $(0.20 \pm 0.03)$, which may affect subsequent generations. Moreover, the herbicide tembotrione was selective to P. elaeisis, showing results comparable to the control. Floristic diversity of weeds can increase food source, habitat, shelter, breeding places and microclimates for insect parasitoids but herbicides formulations can be toxic and these products can affect P. elaeisis or its hosts by direct or indirect contact, showing the importance of selectivity studies for this natural enemy. However, the herbicide tembotrione was selective to $P$. elaeisis and it can be recommended for programs of sustainable management of weeds in corn crop with this parasitoid.
\end{abstract}

Key words: Ecotoxicology, lepidopteran defoliators, parasitoids, pesticides, weed control, Zea mays.

\section{INTRODUCTION}

The corn (Zea mays L.) is cultivated in an area of approximately 13 million hectares in Brazil with a production of 55 million tons (CONAB, 2011). Increasing areas with corn plantations is followed by problems with insect pests and weeds that can reduce production (Sertkaya et al., 2004; Figueiredo et al., 2006). The adoption of sustainable management of weeds in this crop is important for a balance between pests and natural enemies.

Weeds in corn cultivation areas may benefit arthropods and natural enemies. Floristic diversity can increase food source, habitat, shelter, breeding places, and microclimates for insect predators and parasitoids (Steinbauer et al., 2006; Clough et al., 2007; Jonsson et al., 2008; Silva et al., 2010). The use of herbicides to manage weeds is a common practice with low cost and labor and high

\footnotetext{
${ }^{1}$ Universidade Federal dos Vales do Jequitinhonha e Mucuri, PósGraduação em Produção Vegetal, Diamantina, Minas Gerais, Brasil, 39100-000. "Corresponding author (marcusasoares@yahoo.com.br). ${ }^{2}$ Universidade Federal de Viçosa, Departamento de Biologia Animal, Viçosa, Minas Gerais, Brasil, 36570-000.

Received: 21 October 2013.

Accepted: 20 May 2014.
}

doi: $10.4067 /$ S0718-58392014000300016 efficiency (James, 2007; Albajes et al., 2009) to reduce competition with the commercial crop (Constantin et al., 2007). However, herbicides may have direct or indirect adverse effects on natural enemies (Menezes et al., 2012a; 2012b).

Palmistichus elaeisis Delvare and LaSalle, 1993 (Hymenoptera: Eulophidae) is a generalist and gregarious endoparasitoid of Lepidoptera and Coleoptera pupae. This insect oviposits inside the pupae, where the immature feed on host body tissue until the adult stage (Pereira et al., 2008; Zanuncio et al., 2008; Soares et al., 2009). Palmistichus elaeisis parasitized pupae of Spodoptera frugiperda J.E. Smith, 1797 (Lepidoptera: Noctuidae) (Bittencourt and Berti Filho, 2004a; 2004b), demonstrating its importance in integrated pest management (IPM) in corn. Moreover, this parasitoid developed in Tenebrio molitor L., 1785 (Coleoptera: Tenebrionidae), a pest of stored grains. This Coleoptera is reared in the laboratory and available as egg, larva, pupae, and adult stages (Zanuncio et al., 2008).

Herbicides formulations can be toxic to parasitoids (Giolo et al., 2005; Carmo et al., 2009) and these products can affect $P$. elaeisis or its hosts by direct or indirect contact, showing the importance of selectivity studies for this natural enemy. Moreover, inert compounds of herbicide formulations can facilitate penetration of active ingredients through the insect cuticle increasing toxic effect (Malkones, 2000). 
The objective of this study was to evaluate the toxicity of four herbicides, used and registered for corn crop in Brazil, on reproduction and development of the pupae parasitoid, P. elaeisis.

\section{MATERIALS AND METHODS}

The study was conducted in a room at $25 \pm 2{ }^{\circ} \mathrm{C}, 70 \pm$ $10 \% \mathrm{RH}$ and a photoperiod of 12:12 h (500 lumens). One thousand larvae of $T$. molitor were placed in a polystyrene tray with wheat bran buds and sugar cane until pupation (Zanuncio et al., 2008). The polyphagous habit of $P$. elaeisis favors the use of T. molitor as host in toxicity studies (Soltani et al., 1996; Kostaropoulos et al., 2001).

Palmistichus elaeisis was reared in glass test tubes $(14 \times 2.2 \mathrm{~cm})$ plugged with cotton swab. A drop of honey was placed within each tube (Zanuncio et al., 2008). One $24 \mathrm{~h}$ old $T$. molitor pupae was placed per tube with six P. elaeisis females for $48 \mathrm{~h}$. Parasitoids from this rearing were used in this research.

\section{Herbicides treatment}

Fifty $48 \mathrm{~h}$ old $T$. molitor pupae with average weight of $0.104 \mathrm{~g}$ and surface area of $7.8 \times 10^{-5} \mathrm{~m}^{2}$ were dipped in herbicides diluted to $1 \mathrm{~L}$ solution, for $2 \mathrm{~s}$ and then removed. This methodology is efficient for toxicological tests for pupae received herbicide all over its surface and avoids death of pupae by asphyxiation (Vieira et al., 2001). After this, pupae were put in contact with $P$. elaeisis female for $2 \mathrm{~d}$ in the glass tube.

The herbicides used were atrazine (6-chloro- $N^{2}$-ethyl$N^{4}$-isopropyl-1,3,5-triazine-2,4-diamine, $\quad$ Primoleo $\left.®\right)$ (T1), nicosulfuron (1-(4,6-dimethoxypyrimidin-2-yl)-3(3-dimethylcarbamoyl-2-pyridylsulfonyl)urea, Sanson $\left.{ }^{\circledR}\right)$ (T2), paraquat (1,1'-dimethyl-4,4'-bipyridinium, Gramoxone $\left.{ }^{\circledR}\right)$ (T3), tembotrione (2-\{2-chloro-4-mesyl3-[(2,2,2-trifluoroethoxy)methyl]benzoyl\}cyclohexane1,3-dione, Soberan ${ }^{\circledR}$ ) (T4), registered for the corn crop in Brazil and the control had only deionized water (T5). Solutions were prepared considering a volume equivalent to $150 \mathrm{~L} \mathrm{ha}^{-1}$, average surface area of the pupae and commercial dose of each herbicide (MAPA, 2011). Doses of active ingredient $(\mu \mathrm{L})$ per pupa, manufacturer products, chemical groups, toxicology and formulation, and treatments are presented in Table 1.

\section{Evaluated parameters}

Each treatment had 10 replicates, with one pupae of T. molitor and six $72 \mathrm{~h}$ old P. elaeisis females, sexed according to the characteristics of the antennae and abdomen (Delvare and LaSalle, 1993). Pupae exposed to parasitism in the tubes were removed after $48 \mathrm{~h}$ and individualized in $250 \mathrm{~mL}$ plastic pots for $40 \mathrm{~d}$ and those without emergence of parasitoids discarded at the end of this period.

The longevity of $P$. elaeisis females exposed to $T$. molitor pupae treated with the herbicides was evaluated daily. The duration of the life cycle (egg to adult), percentage of parasitism, discounting the host natural mortality (Abbott, 1925), percentage of emergence of the progeny, numbers of males and females emerged, females produced per female, sex ratio, width of head capsule, and body length of parasitoids emerged per T. molitor pupae were obtained. The width of the head capsule and body length of $P$. elaeisis was obtained with a stereoscopic microscope (integrated digital camera and software measurement micrometer, DCM-Series, Cisco Systems, San Jose, California, USA). The sex ratio was calculated with the equation $\mathrm{RS}=$ number of females/total number of individuals.

\section{Statistical analysis}

Data were subjected to tests of the assumptions of the mathematical model (normality and homogeneity of variances) and ANOVA. Significant means were compared with the Tukey's test at $P=0.05$ probability. Nonparametric data were subjected to Kruskal-Wallis test, $P=0.05$ with the program for statistical analysis SAEG (Sistema para Análises Estatísticas, Versão 9.1, SAEG, 2007).

Table 1. Technical characteristics of herbicides registered for corn in Brazil.

\begin{tabular}{|c|c|c|c|c|c|}
\hline $\begin{array}{l}\text { Commercial formulation }{ }^{1} \\
\text { (Manufacturer) }\end{array}$ & $\begin{array}{l}\text { Active ingredient } \\
\text { (ai) (concentration) }\end{array}$ & $\begin{array}{l}\text { Dose per hectare } \\
\text { (ai) }\end{array}$ & $\begin{array}{c}\text { Dose per } \\
\text { pupae (ai) }\end{array}$ & $\begin{array}{l}\text { Chemical } \\
\text { group }\end{array}$ & $\begin{array}{l}\text { Toxicology } y^{2} \text { and } \\
\text { formulation }^{3}\end{array}$ \\
\hline & $\longrightarrow$ & + & $\mu \mathrm{L}$ & & \\
\hline Primoleo (Syngenta) & Atrazine (400) & 2400 & 18.72 & Triazines & $\begin{array}{l}\mathrm{CT}=\mathrm{IV} \\
\mathrm{CA}=\mathrm{II} \\
\mathrm{SC}\end{array}$ \\
\hline Sanson 40 (Ishihara) & Nicosulfuron (4) & 6 & 0.05 & Sulfonylurea & $\begin{array}{l}\mathrm{CT}=\mathrm{IV} \\
\mathrm{CA}=\mathrm{II} \\
\mathrm{SC}\end{array}$ \\
\hline Gramoxone 200 (Syngenta) & Paraquat (200) & 600 & 4.68 & Bipyridine & $\begin{array}{l}\mathrm{CT}=\mathrm{II} \\
\mathrm{CA}=\mathrm{II} \\
\mathrm{SC}\end{array}$ \\
\hline Soberan (Bayer SA) & Tembotrione (420) & 100 & 0.78 & Benzoylcyclehexanedione & $\begin{array}{l}\mathrm{CT}=\mathrm{III} \\
\mathrm{CA}=\mathrm{III} \\
\mathrm{SC}\end{array}$ \\
\hline
\end{tabular}

${ }^{1}$ Trademark of the manufacturer.

${ }^{2} \mathrm{CT}$ : toxicological class (I: extremely toxic; II: highly toxic; III: moderated toxic; IV: low toxicity), CA: environmental classification (I: highly dangerous; II: very dangerous; III: hazardous; IV: slightly hazardous).

${ }^{3} \mathrm{SC}$ : suspension concentrate. 


\section{RESULTS AND DISCUSSION}

\section{Longevity of adults}

Longevity of P. elaeisis adults exposed to T. molitor pupa was higher with atrazine and nicosulfuron, but lower with paraquat, tembotrione, and water $(F=16.635, P=0.000)$ (Figure 1).

The herbicide atrazine and nicosulfuron may have caused the rejection of P. elaeisis females to T. molitor pupae and therefore its females had lower metabolic energy use. The largest energy reserves allowed these females to present longer longevity with these herbicide treatments compared to tembotrione and water. Atrazine was harmless (mortality < 30\%) to adults of the parasitoid Trichogramma pretiosum Riley, 1879 (Hymenoptera: Trichogrammatidae) exposed for $6 \mathrm{~d}$ to this product (Stefanello Junior et al., 2008). The mixture of atrazine and nicosulfuron, however, reduced the number of individuals of Collembola (Arthropoda: Ellipura), mites (Acari) and ants (Hymenoptera: Formicidae) (Vilma et al., 2007; Pereira et al., 2009).

Biological processes require energy, which is a limiting factor. Energy balances may occur in physiological processes where the energy available to a process decreases the energy to supply others (Calow and Sibly, 1990). Therefore, the lowest longevity of $P$. elaeisis in treatments with water and tembotrione, corroborates with the allocation of energy to reproduction process. Consequently, female longevity of these treatments decreased. The reduced longevity of P. elaeisis females after exposure to T. molitor pupae treated with paraquat may be due to toxicity of this herbicide (Figure 1). Paraquat, in single formulation (only the active ingredient) or in combination (paraquat + diuron), caused mortality and reduced parasitism rate of $T$. pretiosum and

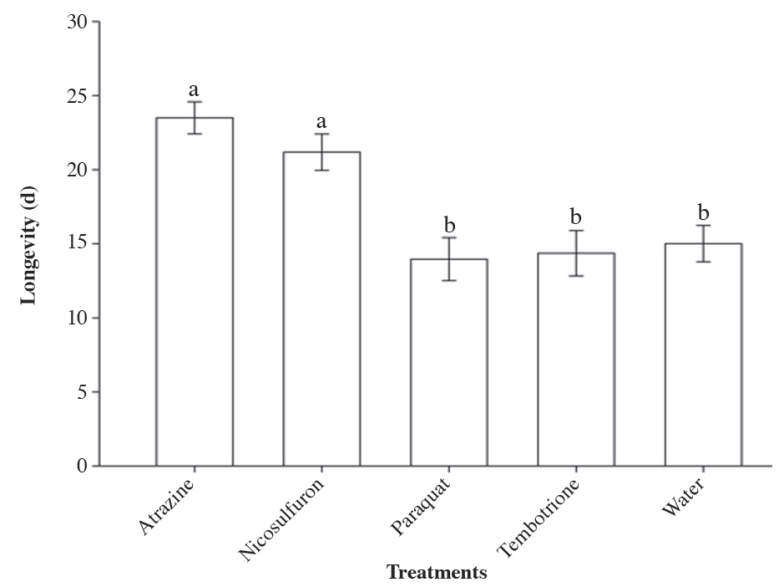

Means followed by the same letter do not differ according to Tukey's test $(P=0.05) .(F=16.635, P=0.0000)$.

Figure 1. Longevity (mean \pm standard deviation) of Palmistichus elaeisis (Hymenoptera: Eulophidae) females after exposure to Tenebrio molitor (Coleoptera: Tenebrionidae) pupae treated with herbicides registered for the corn crop in Brazil.
Anisopteromalus calandrae Howard, 1881 (Hymenoptera: Pteromalidae) (Bastos et al., 2005; Stefanello Junior et al., 2008; Lacoume et al., 2009).

\section{Parasitism}

Parasitism of P. elaeisis females was $30 \%$ and $40 \%$ with atrazine and paraquat without emergency of adults, and higher with tembotrione and water, $80 \%$ and $90 \%$ respectively $(F=31.174, P=0.002)$ (Table 2$)$.

The low selectivity of the herbicides atrazine and paraquat to P.elaeisis immature stages was similar to results with the commercial formulation of Gesaprim ${ }^{\circledR}$ GrDA and Gesaprim ${ }^{\circledR} 50$ (atrazine) with 30\%-79\% mortality of adults of the parasitoid Trichogramma cacoeciae March, 1927 (Hymenoptera: Trichogrammatidae) (Hassan et al., 1988). However, paraquat was selective to Telenomus remus Nixon, 1937 (Hymenoptera: Scelionidae) parasitizing S. frugiperda (Carmo et al., 2009). This showed that susceptibility to the herbicides atrazine and paraquat varies with parasitoid species.

Females emerged and development of immature stages The number of emerged P. elaeisis females was lower with nicosulfuron $(20 \%)$ and had similar values with tembotrione and water $(80 \%$ and $90 \%$, respectively; $F=$ $21.474, P=0.000$ ) (Table 2). Tembotrione did not affect the development of $P$. elaeisis immature stages.

The herbicide nicosulfuron can be toxic to P. elaeisis as reported for T. pretiosum and to non-targeted organisms such as immature of the fish Carassius auratus L., 1758 (Cypriniformes: Cyprinidae), inhibiting the activity of a metabolite in its brain (Bretauda et al., 2000; Stefanello Junior et al., 2008). The nicosulfuron also affected the metabolism of the algae Chlorella vulgaris Kessler and Huss, 1992 (Chlorococcales: Oocystaceae), Navicula accommoda f. robusta Foged, 1982 (Naviculales: Naviculaceae) and Oscillatoria limnetica Lemmermann, 1900 (Oscillatoriales: Oscillatoriaceae) (Leboulanger et al., 2001).

\section{Females produced per female and sex ratio}

The emergence of $P$. elaeisis and females produced per female were higher with tembotrione and in the control, but lower with nicosulfuron $(F=21.074, P=0.000)$ (Table 2). The sex ratio of parasitoid was lower with nicosulfuron (0.2) and higher with tembotrione and water (0.8 and 0.9, respectively; $F=9.439, P=0.0008$ ) (Table 2).

The highest values of adult emergence and female produced per $P$. elaeisis female with tembotrione and water were similar to that of this parasitoid with pupae of this host without treatment (Zanuncio et al., 2008). However, the sex ratio with nicosulfuron can affect population dynamics of $P$. elaeisis due to the lower number of females compared to tembotrione and water. Melittobia clavicornis Cameron, 1908, Melittobia australica Girault, 
Table 2. Reproductive variables (mean \pm standard deviation) of the first generation of Palmistichus elaeisis (Hymenoptera: Eulophidae) from pupae of Tenebrio molitor (Coleoptera: Tenebrionidae) treated with herbicides registered for corn crop in Brazil.

\begin{tabular}{|c|c|c|c|c|c|}
\hline Reproductive variables & Atrazine & Nicosulfuron & Paraquat & Tembotrione & Water \\
\hline Duration of life cycle, $d$ & - & $21.00 \pm 2.82 \mathrm{a}$ & - & $21.30 \pm 2.13 a$ & $23.00 \pm 1.81 \mathrm{a}$ \\
\hline Parasitism, $\% 1$ & $30.0 \mathrm{~b}$ & $50.0 \mathrm{ab}$ & $40.0 \mathrm{ab}$ & $80.0 \mathrm{a}$ & $90.0 \mathrm{a}$ \\
\hline Emergence, $\% 1$ & - & $20.0 \mathrm{~b}$ & - & $80.0 \mathrm{a}$ & $90.0 \mathrm{a}$ \\
\hline Number of individuals & - & $5.70 \pm 3.70 b$ & - & $56.60 \pm 17.5 \mathrm{a}$ & $80.90 \pm 23.0 \mathrm{a}$ \\
\hline Females produced per female & - & $0.80 \pm 0.05 b$ & - & $8.30 \pm 0.30 a$ & $11.90 \pm 0.40 a$ \\
\hline Head capsule of females, $\mathrm{mm}$ & - & $0.43 \pm 0.03 a$ & - & $0.45 \pm 0.03 \mathrm{a}$ & $0.59 \pm 0.03 a$ \\
\hline Head capsule of males, $\mathrm{mm}$ & - & $0.37 \pm 0.03 \mathrm{a}$ & - & $0.40 \pm 0.02 \mathrm{a}$ & $0.40 \pm 0.02 \mathrm{a}$ \\
\hline Length of females, $\mathrm{mm}$ & - & $1.95 \pm 0.04 b$ & - & $2.10 \pm 0.10 \mathrm{a}$ & $2.07 \pm 0.11 \mathrm{a}$ \\
\hline Length of males, $\mathrm{mm}$ & - & $1.78 \pm 0.04 \mathrm{a}$ & - & $1.58 \pm 0.08 b$ & $1.60 \pm 0.10 b$ \\
\hline Longevity of females, $\mathrm{d}$ & - & $29.00 \pm 3.27 \mathrm{a}$ & - & $18.00 \pm 4.20 \mathrm{a}$ & $28.00 \pm 3.01 \mathrm{a}$ \\
\hline Longevity of males, $\mathrm{d}$ & - & $27.10 \pm 3.98 \mathrm{a}$ & - & $22.90 \pm 4.00 \mathrm{a}$ & $26.00 \pm 3.46 \mathrm{a}$ \\
\hline Sex ratio & - & $0.20 \pm 0.03 b$ & - & $0.80 \pm 0.05 \mathrm{a}$ & $0.90 \pm 0.02 \mathrm{a}$ \\
\hline
\end{tabular}

Means followed by the same letter per row do not differ according to Tukey's test $(P=0.05)$.

${ }^{1}$ Means followed by same letter per row do not differ according to Kruskal-Wallis test $(P=0.05)$.

1912 and Melittobia digitata Dahms, 1984 (Hymenoptera: Eulophidae) showed a sex ratio of 0.97, 0.95, and 0.95, respectively (Silva-Torres and Matthews, 2003; González et al., 2004), suggesting that this rate is characteristic of this family.

\section{Width of head capsule and body length}

The width of the head capsule of $P$. elaeisis males and females was similar, but their body length varied between treatments, with higher values for females treated with tembotrione and water $(2.096$ and $2.071 \mathrm{~mm}$, respectively), and for males with nicosulfuron (1.778 $\mathrm{mm}, F=27.420, P=0.0000$ ) (Table 2 ). The body length of females $(1.948 \mathrm{~mm})$ was lower with nicosulfuron $(F=$ 43.986, $P=0.0000$ ) (Table 2).

The shorter length of the body of P. elaeisis females with nicosulfuron may be due to toxicity of this herbicide, as evidenced by fewer parasitoids emerged.

\section{Longevity of both sexes}

The longevity of P.elaeisis females and males was similar with the herbicides tembotrione $(18.0 \pm 4.20$ and $22.9 \pm$ $4.00 \mathrm{~d})$, nicosulfuron $(29.0 \pm 3.27$ and $27.1 \pm 3.98 \mathrm{~d})$ and water $(28.0 \pm 3.01$ and $26.0 \pm 3.46 \mathrm{~d}$, respectively; $F=$ $3.507, P=0.0543$ ) (Table 2).

The longevity of $P$. elaeisis with nicosulfuron, tembotrione, and water shows that the herbicides did not affect the first generation, with similar longevity numbers for males and females of this parasitoid in other study, with $22.65 \pm 1.13$ and $28.3 \pm 2.38 \mathrm{~d}$, respectively (Zanuncio et al., 2008).

\section{CONCLUSIONS}

The herbicides atrazine, paraquat, and nicosulfuron were toxic and reduced parasitism and emergence of P.elaeisis. Nicosulfuron reduced the sex ratio of $P$. elaeisis and therefore it should be used with caution or substituted with more selective products. The herbicide tembotrione was selective to $P$. elaeisis and may be suitable for programs of sustainable management of weeds in corn with this parasitoid. More studies are needed, especially in field and using natural hosts to confirm the results obtained in the laboratory.

\section{ACKNOWLEDGEMENTS}

To Conselho Nacional de Desenvolvimento Científico e Tecnológico (CNPq), Coordenação de Aperfeiçoamento de Pessoal de Nível Superior (CAPES), and Fundação de Amparo à Pesquisa do Estado de Minas Gerais (FAPEMIG) for financial support.

\section{LITERATURE CITED}

Abbott, W.S. 1925. A method of computing the effectiveness of an insecticide. Journal of Economic Entomology 18:265-267.

Albajes, R., B. Lumbierres, and X. Pons. 2009. Responsiveness of arthropod herbivores and their natural enemies to modified weed management in corn. Environmental Entomology 38:944-954. doi:10.1603/022.038.0349

Bastos, C.S., R.P. Almeida, and F.A. Suinaga. 2005. Selectivity of pesticides used on cotton (Gossypium hirsutum) to Trichogramma pretiosum reared on two laboratory-reared hosts. Pest Management Science 62:91-98. doi:10.1002/ps.1140.

Bittencourt, M.A.L., e E. Berti Filho. 2004a. Desenvolvimento dos estágios imaturos de Palmistichus elaeisis Delvare \& LaSalle (Hymenoptera: Eulophidae) em pupas de Lepidoptera. Revista Brasileira de Entomologia 48:65-68. doi:10.1590/S008556262004000100012 .

Bittencourt, M.A.L., e E. Berti Filho. 2004b. Exigências térmicas para o desenvolvimento de Palmistichus elaeisis (Hymenoptera: Eulophidae) em pupas de cinco espécies de lepidópteros. Iheringia Série Zoologia 94:321-323. doi:10.1590/S007347212004000300016

Bretaud, S., J.P. Toutant, and P. Saglio. 2000. Effects of carbofuran, diuron, and nicosulfuron next term on acetylcholinesterase activity in goldfish (Carassius auratus). Ecotoxicology and Environmental Safety 47:117-124. doi:10.1006/eesa.2000.1954.

Calow, P., and R.M. Sibly. 1990. A physiological basis of populations processes: ecotoxicological implications. Functional Ecology 4:283-288.

Carmo, E.L., A.F. Bueno, R.C.O.F. Bueno, S.S. Vieira, A.L. Gobbi, e F.R. Vasco. 2009. Seletividade de diferentes agrotóxicos usados na cultura da soja ao parasitoide de ovos Telenomus remus. Ciência Rural 39:2293-2300. doi:10.1590/S0103-84782009005000188.

Clough, Y., A. Kruess, and T. Tscharntke. 2007. Local and landscape factors in differently managed arable fields affect the insect herbivore community of a non-crop plant species. Journal of Applied Ecology 44:22-28. doi:10.1111/j.13652664.2006.01239.x. 
CONAB. 2011. Acompanhamento de safra brasileira: Grãos, Terceiro levantamento. Companhia Nacional de Abastecimento (CONAB), Brasília DF, Brasil. Available at http://www.conab. gov.br (accessed 13 January 2013).

Constantin, J., R.S.I. Oliveira Júnior, S.D. Cavalieri, J.G.Z. Arantes, D.G. Alonso, A.C. Roso, et al. 2007. Interação entre sistemas de manejo e de controle de plantas daninhas em pós-emergência afetando o desenvolvimento e a produtividade do milho. Planta Daninha 25:513-520. doi:10.1590/S0100-83582007000300010.

Delvare, G., and J.A. LaSalle. 1993. New genus of Tetrastichinae (Hymenoptera: Eulophidae) from the neotropical region, with the description of a new species parasitica on key pests of oil palm. Journal of Natural History 27:435-444. doi:10.1080/00222939300770201.

Figueiredo, M.L.C., A.M.P. Martins-Dias, and I. Cruz. 2006. Relationship between fall armyworm larvae and its natural biological control agents in maize yield. Pesquisa Agropecuária Brasileira 41:1693-1698. doi:10.1590/S0100204X2006001200002.

Giolo, F.P., A.D. Grützmacher, S.O. Procópio, C.G. Manzoni, C.A.B. Lima, and S.D. Nörnberg. 2005. Seletividade de formulações de glyphosate a Trichogramma pretiosum (Hymenoptera: Trichogrammatidae). Planta Daninha 23:457-462. doi:10.1590/ S0100-83582005000300009.

González, J.M., J. Abe, and R.W. Matthews. 2004. Offspring production and development in the parasitoid wasp Melittobia clavicornis (Cameron) (Hymenoptera: Eulophidae) from Japan. Entomological Science 7:15-19. doi:10.1111/j.14798298.2003.00039.x.

Hassan, S.A., F. Bigler, H. Bogenschütz, E. Boller, J. Brun, P. Chiverton, et al. 1988. Results of the fourth joint pesticide testing programme carried out by the IOBC/WPRS-Working Group "Pesticides and Beneficial Organisms". Journal of Applied Entomology 105:321-329. doi:10.1111/j.1439-0418.1988. tb00194.x.

James, C. 2007. Global status of commercialized Biotech/GM crops: 2007. The International Service for the Acquisition of Agribiotech Applications (ISAAA) Brief nr 37. 166 p. ISAAA, Ithaca, New York, USA.

Jonsson, M., S.D. Wratten, D.A. Landis, and G.M. Gurr. 2008. Recent advances in conservation biological control of arthropods by arthropods. Biological Control 45:172-175. doi:10.1016/j. biocontrol.2008.01.006.

Kostaropoulos, I., A.I. Papadopoulos, A. Metaxakis, E. Boukouvala, and E. Papadopoulou-Mourkidou. 2001. The role of glutathione S-transferases in the detoxification of some organophosphorus insecticides in larvae and pupae of the yellow mealworm, Tenebrio molitor (Coleoptera: Tenebrionidae). Pest Management Science 57:501-508. doi:10.1002/ps.323.

Lacoume, S., C.C. Bressa, and C. Chevrier. 2009. Male hypofertility induced by Paraquat consumption in the nontarget parasitoid Anisopteromalus calandrae (Hymenoptera: Pteromalidae). Biological Control 49:214-218. doi:10.1016/j. biocontrol.2009.02.002.

Leboulanger, C., F. Rimet, M.H. Lacotte, and A. Bérard. 2001. Effects of atrazine and nicosulfuron next term on freshwater microalgae. Environment International 26:131-135. doi:10.1016/ S0160-4120(00)00100-8.

Malkones, H.P. 2000. Comparison of the effects of differently formulated herbicides on soil microbial activities a review. Journal of Plant Diseases and Plant Protection 8:781-789.

MAPA. 2011. Sistema de Agrotóxicos Fitossanitários Agrofit. Ministério da Agricultura Pecuária e Abastecimento (MAPA), Brasília DF, Brasil. Available at http://extranet.agricultura.gov.br/ agrofit_cons/principal_agrofit_cons (accessed 3 November 2011).

Menezes, C.W.G., J.B. Santos, S.L. Assis Júnior, A.C. França, A.J. Fonseca, M.A. Soares, et al. 2012b. Seletividade de atrazine e nicossulfuron a Podisus nigrispinus (Heteroptera: Pentatomidae). Planta Daninha 30:327-334. doi:10.1590/S010083582012000200011.
Menezes, C.W.G., M.A. Soares, J.B. Santos, S.L. Assis Júnior, A.J. Fonseca, and J.C. Zanuncio. 2012a. Reproductive and toxicological impacts of herbicides used in Eucalyptus culture in Brazil on the parasitoid Palmistichus elaeisis (Hymenoptera: Eulophidae). Weed Research 52:520-525. doi:10.1111/j.13653180.2012.00938.x.

Pereira, F.F., J.C. Zanuncio, J.E. Serrão, P.L. Pastori, and F.S. Ramalho. 2009. Reproductive performance of Palmistichus elaeisis Delvare and LaSalle (Hymenoptera: Eulophidae) with previously refrigerated pupae of Bombyx mori L. (Lepidoptera: Bombycidae). Brazilian Journal of Biology 69:865-869. doi:10.1590/S1519-69842009000400014

Pereira, F.F., T.V. Zanuncio, J.C. Zanuncio, D. Pratissoli, and M.T. Tavares. 2008. Species of Lepidoptera defoliators of eucalypt as new hosts for the polyphagous parasitoid Palmistichus elaeisis (Hymenoptera: Eulophidae). Brazilian Archives of Biology and Technology 51:259-262. doi:10.1590/S151689132008000200004

SAEG. 2007. Sistema para Análises Estatísticas (SAEG). Fundação Arthur Bernardes, Universidade Federal de Viçosa, Viçosa, Brasil. Available at http://www.ufv.br/saeg/ (accessed in January 2012).

Sertkaya, E., A. Bayram, and S. Kornosor. 2004. Egg and larval parasitoids of the beet armyworm Spodoptera exigua on maize in Turkey. Phytoparasitica 32:305-312. doi:10.1007/BF02979825.

Silva, E.B., J.C. Franco, T. Vasconcelos, and M. Branco. 2010. Effect of ground cover vegetation on the abundance and diversity of beneficial arthropods in citrus orchards. Bulletin of Entomological Research 100:489-499. doi:10.1017/S0007485309990526.

Silva-Torres, C.S.A., and R.W. Matthews. 2003. Development of Melittobia australica Girault and M. digitata Dahms (Parker) (Hymenoptera: Eulophidae) parasiting Neobellieria bullata (Parker) (Diptera: Sarcophagidae) puparia. Neotropical Entomology 32:645-651. doi:10.1590/S1519566X2003000400015.

Soares, M.A., C.T. Gutierrez, J.C. Zanuncio, A.R.P. Pedrosa, y A.S. Lorenzon. 2009. Superparasitismo de Palmistichus elaeisis (Hymenoptera: Eulophidae) y comportamiento de defensa de dos hospederos. Revista Colombiana de Entomología 35:62-65.

Soltani, N., N. Soltani-Mazouni, and J. Delachambre. 1996. Evaluation of triflumuron, a benzoylphenylurea derivative, on Tenebrio molitor pupae (Col: Tenebrionidae): Effects on cuticle. Journal of Applied Entomology 120:627-629. doi:10.1111/j.1439-0418.1996.tb01662.x.

Stefanello Junior, G.J., A.D. Grützmacher, D.D. Grützmacher, C.A.B. Lima, D.O. Dalmozo, e M.D.F. Paschoal. 2008. Seletividade de herbicidas registrados para a cultura do milho a adultos de Trichogramma pretiosum (Hymenoptera: Trichogrammatidae). Planta Daninha 26:343-351. doi:10.1590/ S0100-83582008000200010

Steinbauer, M.J., M.W. Short, and S. Schmidt. 2006. The influence of architectural and vegetational complexity in eucalypt plantations on communities of native wasp parasitoids: Towards silviculture for sustainable pest management. Forest Ecology and Management 233:153-164.

Vieira, A., L. Oliveira, and P. Garcia. 2001. Effects of conventional pesticides on the pre imaginal developmental stages and on adults of Trichogramma cordubensis (Hymenoptera: Trichogrammatidae). Biocontrol Science and Technology 11:527534. doi:10.1080/09583150120067553.

Vilma, S.L., H.R. Santos, and M.C. Gonçalves. 2007. The effect of the glyphosate, 2,4-D, atrazine and nicosulfuron herbicides upon the edaphic Collembola (Arthropoda: Ellipura) in a no tillage system. Neotropical Entomology 36:261-267. doi:10.1590/ S1519-566X2007000200013.

Zanuncio, J.C., F.F. Pereira, G.C. Jacques, M.T. Tavares, and J.E. Serrão. 2008. Tenebrio molitor Linnaeus (Coleoptera: Tenebrionidae), a new alternative host to rear the pupae parasitoid Palmistichus elaeisis Delvare \& Lasalle (Hymenoptera: Eulophidae). The Coleopterists Bulletin 62:64-66. doi: $10.1649 / 1015.1$ 